НАУКОВИЙ ВІСНИК

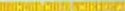

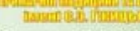

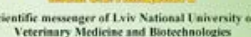

7

(1)

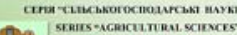

Tow 21 Nis 90

2019
Науковий вісник Дьвівського національного університету ветеринарної медицини та біотехнологій імені С.3. Гжицького. Серія: Сільськогосподарські науки

Scientific Messenger of Lviv National University of Veterinary Medicine and Biotechnologies.

Series: Agricultural sciences

UDC 636.4.085.27

\title{
The effective use of biologically active substance that belongs to hydrolyse class "Lysozyme G3" in the composition of pigs premix
}

\author{
A.Y. Karunskiy, I.V. Nikolenko \\ Odessa State Agrarian University, Odessa, Ukraine
}

Article info

Received 14.02.2019

Received in revised form 18.03.2019

Accepted 19.03.2019

Odessa State Agrarian University, Kanatna St., 13, Odessa, 65012, Ukraine.

Tel.: +38-048-734-88-28

E-mail: igor.nikolenko.87@ukr.net
Karunskiy, A.Y., \& Nikolenko, I.V. (2019). The effective use of biologically active substance that belongs to hydrolyse class "Lysozyme G3" in the composition of pigs premix. Scientific Messenger of Lviv National University of Veterinary Medicine and Biotechnologies. Series: Agricultural sciences, 21(90), 93-97. doi: 10.32718/nvlvet-a9016

This article presents the results of the effective use of biologically active substance that belongs to hydrolyse class "Lysozyme G3" in the composition of pigs premix. New premix that can balance the main grains in pigs feeding has been developed. The main grains are wheat, corn, barley. These compounds are included into pigs feeding ration and they are the main crops in the South of Ukraine. The effect of using this new premix that contains the enzyme preparation "Lysozyme G3" for fattening pigs was also investigated. The productive effect of enzyme preparation in the rations with the same nutritional value for fattening pigs and its effect on the nutrients digestibility were studied. Experimental research activities were conducted at the agricultural enterprise "Avangard-D" LLC, Ovidiopol District, Odessa Oblast. The changes in live weight, as well as gains of fattening pigs at the age of 4, 5, 6 and 7 months were studied in the scientific and economical experience. During the main period (120 days), the increase in pigs live weight was observed in all groups. Thus, in the control group, this indicator changed from 27.8 to $107 \mathrm{~kg}$; in II experimental group - from 28.1 to 109.2; in III experimental group - from 28.0 to $111.7 \mathrm{~kg}$. When removing animals from fattening, the difference in live weight between the III experimental and control groups was $4.4 \%$ and it was statistically significant $(P>0.95)$. The average daily gains in piglets of II and III experimental groups significantly exceeded the indices of control one by $2.4 \%$ and $5.7 \%$, respectively. The nutrients digestibility in animals of all experimental groups was studied to analyze more carefully. The analysis of digestibility indices in pigs rations during experiment (when pigs are fed with premix that contains biologically active substance Lysozyme G3), and its content in the ration indicated that nutrient digestibility indices had changed into the direction of increase. Feed consumption was calculated after analyzing these indices. Thus, the smallest feed consumption per unit of live weight gain was established in the third experimental group, where it was 3.2 feed units and was less in comparison with animals of the control group by 3.4\%. During scientific and economical researches, blood samples were taken from animals of the first control group and the third experimental one for morphological and biochemical studies. It was found that the blood parameters of experimental animals during the entire period of fattening were within the physiological norm. The amount of protein in the blood indicates that animals of experimental group have higher growth rate by 10.9\%. The economic indicators directly reflected above mentioned facts when the calculation of the economic part of the research were carried out. Thus, we got 1870.5 UAH from the first group, 1934.3 UAH from the second group, 1989.4 UAH from the third group, selling products from one head. Accordingly, the level of profitability of pork production was: in the first group (control) - 13.5; in the second (1 kg/ton of premix) $-16.5 \%$; in the third (2 kg/ton of premix) $-19.8 \%$.

Key words: pigs, premix, biologically active substance belongs to the class of hydrolyse "Lysozyme G3", productivity, digestibility.

\section{Ефективність використання біологііної активної речовини класу гідролаз “Лізоцим ГЗх" у складі преміксу для свиней}

\author{
О.Й. Карунський, І.В. Ніколенко
}




\section{Одеський державний аграрний університет, м. Одеса, Украӥна}

У статті наведені результати ефективності використання біологічно активної речовини класу гідролаз “Лізоцим Гзх” у складі преміксу для свиней. Розроблено новий премікс, який збалансував би основні зернові культури в годуванні свиней. Зокрема, такі як: пшеничя, кукурудза, ячмінь. Ці культури вводяться в раціон свиней і є основними на Півдні Украӥни. Також досліджена дія нового преміксу з ферментним препаратом “Лізоцим Гзх” в годуванні поросят на дорошуванні і свиней на відгодівлі. Вивчена продуктивна дія ферментного препарату на однакових за поживною иінністю раціонах при відгодівлі свиней $і$ його вплив на перетравність поживних речовин рачіону. Експериментальні дослідження були проведені у виробничих умовах господарства ТОВ “Авангард Д” Овідіопольського району Одеської області. У науково-господарському досліді вивчали зміну живої маси, а також прирости свиней на відгодівлі у віці 4, 5, 6 і 7 місяців. Впродовж основного періоду (120 днів) спостерігалося збільшення живої маси свиней в усіх групах. Так, в контрольній групі цей показник змінився з 27,8 до 107 к2; II дослідній - $з$ 28,1 до 109,2; ІІІ дослідній - з 28,0 до 111,7 кг. При знятті тварин з відгодівлі, різниця по живій масі між ІІІ дослідною і І контрольною групами склала 4,4\%, i була статистично достовірною (P > 0,95). Середньодобові прирости живої маси у поросят II і III дослідної групи достовірно перевищували показники контрольної на 2,4\% і 5,7\% відповідно. Для більш детальнішого уявлення, також була вивчена перетравність поживних речовин у тварин в усіх дослідних групах. Аналіз коефіцієнтів перетравності раціонів свиней у балансовому досліді (при згодовуванні їм преміксу з біологічно активною речовиною “Лізоцим Гзх”), і його вміст у раціоні, вказує, щзо коефіцієнти перетравності поживних речовин змінилися у бік збільшення. Проаналізувавщи ці показники, був проведений підрахунок спожитого тваринами корму. Так, найменша витрата кормів на одиницю приросту живої маси була встановлена в ІІІ дослідній групі, де склала 3,2 корм. од. і була менше у порівнянні з тваринами контрольної групи на 3,4\%. В ході науково-господарського досліду у тварин першої контрольної групи і третьої дослідної були відібрані зразки крові для проведення морфологічних $і$ біохімічних показників. Було встановлено, щуо показники крові дослідних тварин впродовж усього періоду відгодівлі знаходилися в межах фізіологічної норми. Кількість білку в крові свідчить, щуо різниця була на користь дослідної групи, де характерна більш висока інтенсивність росту, і була на 10,9\% більше. Вищевикладені факти напряму відобразилася і на економічних показниках при обчисленні економічної частини проведених досліджень. Таким чином, від реалізації продукції однієї голови з периої групи було отримано: 1870,5 грн, другої-1934,3 грн, третьої-1989,4 грн. Відповідно, рівень рентабельності виробництва свинини склав: в першій групі (контрольній) - 13,5; другій (1 кг/тонну преміксу) - 16,5\%; третьої (2 кг/тонну преміксу) - 19,8\%.

Ключові слова: свині, премікс, біологічно активна речовина класу гідролаз "Лізоцим Гзх", продуктивність, перетравність.

\section{Вступ}

Ефективність галузі свинарства значною мірою залежить від організації відгодівлі молодняку та урахування всіх факторів, що впливають на ії результати (Maslak, 2015; Cherniy et al., 2018).

Для досягнення високих показників в галузі свинарства, крім хороших генетичних показників, потрібно мати міцну кормову базу для забезпечення якісними, повнораціонними кормами (Hachkova, 2010).

Для підвищення продуктивності тварин, інтенсифікації процесів розчеплення поживних речовин раціону у шлунково-кишковому тракті, у практиці годівлі використовують різноманітні кормові добавки, премікси, ферментні препарати та інші біологічно активні сполуки (Boyarintsev et al., 2007).

Серед речовин, що відіграють важливу роль в живленні тварин, значне місце займають премікси, які позитивно впливають на ефективне використання поживних речовин раціону (Kozakova, 2008).

Дослідження, по застосуванню преміксів з біологічно активною речовиною класу гідролаз “Лізоцим ГЗх” в свинарстві 3 метою підвищення його продуктивності має на сьогодні важливе науковогосподарське значення, і $є$ актуальним стосовно кожної біогеохімічної зони Ураїни.

Продукти тваринництва, одержані при використанні преміксу 3 біологічно активною речовиною класу гідролаз “Лізоцим ГЗх" є абсолютно безпечним i екологічно чистим, так, як ферменти на відміну від біостимуляторів і інших кормових добавок діють не на організм тварин, а на компоненти корму в шлунково-кишковому тракті, то вони не накопичуються в організмі й продуктах тваринництва (Anisova et al., 2014).

У зв'язку з цим, знання використання преміксу з біологічно активної речовини класу гідролаз “Лізоцим
ГЗх", дозволяє прогнозувати досягнення високої продуктивності свиней.

Мета і завдання дослідження. Виходячи 3 цих передумов, ми поставили перед собою завдання, розробити новий премікс, який би збалансовував основні зернові культури в годівлі свиней, такі як: пшениця, кукурудза, ячмінь. Ці культури впроваджуются у годівлю свиней, та являются основними на Півдні України. А також, дослідити в складі преміксу дію ферментного препарату “Лізоцим ГЗх" (який ще не застосовувався в годівлі свиней у нашій державі) в годівлі поросят на дорощувані та свиней на відгодівлі, а саме:

- провести хімічний аналіз корму;

- дослідити вплив нового премікса 3 ферментним препаратом “Лізоцим ГЗх" на перетравність поживних речовин;

- визначити зміну живой маси середньодобових приростів піддосліних тварин;

- проаналізувати біохімічні та геметологічні показники крові;

- простежити економічну ефективність згодовуваного премікса 3 ферментним препаратом “Лізоцим ГЗх".

\section{Матеріал і методи досліджень}

Експериментальні дослідження були проведені в виробничих умовах господарства ТОВ “Авангард-Д” Овідіопольського району, Одеської області. В основу роботи поставлене завдання створення премікса для свиней, збагаченого ферментним препаратом "Лізоцим ГЗх" та вивчення його дії на продуктивність поросят на дорощуванні та відгодівлі.

Для досліду, було відібрано 36 голів піддослідних тварин, розділенно їх на 3 групи, по 12 голів у кожній (перша група залишалась контрольною). Дослідні 
групи отримували премікс 3 додаванням до нього ферментного препарату у кількості 1 і 2 кг на 1 тонну преміксу, контрольна група отримувала основний раціон без додавання до преміксу ферментного препарату. Формування піддослідних груп проводили за принципом аналогів з урахуванням порідності, віку, живої маси, енергії росту, походження та фізіологічного стану. Схема повного циклу досліджень наведена у табл. (1).

Таблиця 1

Молодняк на відгодівлі від 3 до 8-місячного віку

\begin{tabular}{|c|c|c|c|}
\hline \multirow[b]{2}{*}{ Період досліду } & \multicolumn{3}{|c|}{ Групи тварин } \\
\hline & $\begin{array}{c}\text { I (контрольна) } \\
\mathrm{n}=12\end{array}$ & $\begin{array}{l}\text { II (піддослідна) } \\
\text { n = } 12 \\
\end{array}$ & $\begin{array}{c}\text { III (піддослідна) } \\
\text { n = } 12\end{array}$ \\
\hline Підготовчий період 10 діб & \multicolumn{3}{|c|}{ Основний раціон (OP) } \\
\hline Дослідний 120 діб & $\begin{array}{l}\text { Основний раціон } \\
\text { (ОР) без преміксу } \\
\text { з “Лізоцим Г3х" }\end{array}$ & $\begin{array}{c}\text { Основний раціон (OP) з } 1 \text { кг } \\
\text { препарату на тонну преміксу, у } \\
\text { розрахунку } 1 \% / \text { т (OP) }\end{array}$ & $\begin{array}{c}\text { Основний раціон (ОР) з } 2 \text { кг препа- } \\
\text { рату на тонну преміксу, у розраху- } \\
\text { нку } 1 \% / \text { (OP) }\end{array}$ \\
\hline
\end{tabular}

До початку господарських досліджень, були відібрані зразки кормів і в умовах лабораторій кафедри генетики, розведення та годівлі с.-г. тварин ОДАУ та інституту Одеська Філія ДУ “Інститут Охорони Грунтів України”, вивчено їх хімічний склад та можливість ефективного використання на підставі одержаних даних.

Отримані дані були проаналізовані, і кількість кожної культури, для згодовування, підбиралась за фізіологічною потребою тварин за загальноприйнятим нормам (Karuns'kyi, 2004; Ibatulin et al., 2013), а також, з раціонально-економічної точки зору. Відсоткова частина кожної культури становила: кукурудза $10 \%$; ячмінь $38 \%$; пшениця 42\%; соняшниковий шрот $8 \%$; трикальцій фосфат 0,6 ; сіль 0,4 ; премікс $1 \%$.

Таким чином, поживність одного кілограму відбалансованого корму становила: 1,2 кормових одиниць, кількість обмінної енергії - 13,08 Мдж, вміст перетравного протеїну - 114,4 г, кальцію - 6,8 г та фосфору 5,9 г.

\section{Таблиця 2}

Динаміка живої маси та приростів піддослідних тварин

\section{Результати та їх обговорення}

У науково-господарському досліді вивчали зміну живої маси, а також, прирости свиней на відгодівлі. 3 цією метою проводили їх індивідуальні зважування у віці 4, 5, 6 та 7 місяців. Зважування проводили вранці перед годівлею.

Аналіз даних таблиці 2 вказує, що найвища жива маса тварин в 7 місяців, була отримана в III дослідній групі, що одержувала 3 раціоном “Лізоцим ГЗх" кількості 2 кг на тонну преміксу.

Протягом основного періоду (120 днів) жива маса свиней по групах збільшилося в контрольній групі 3 27,8 до 107 кг; II дослідній - з 28,1 до 109,2; III дослідній - 3 28,0 до 111,7 кг. При знятті тварин з відгодівлі, різниця за живою масою між III дослідною та контрольною групами склала 4,4\% і була статистично вірогідною $(\mathrm{P}>0,95)$.

Інтенсивність росту живої маси тварин в групах, також, була не однаковою, і абсолютний приріст за весь період досліджень, був різним та складав 79,3; 81,$1 ; 83,7$ кг.

\begin{tabular}{|c|c|c|c|c|c|c|}
\hline \multirow{2}{*}{$\begin{array}{l}\text { Група } \\
\text { тварин }\end{array}$} & \multirow{2}{*}{ Показники } & \multirow{2}{*}{$\begin{array}{c}\text { При поста- } \\
\text { новці на дослід }\end{array}$} & \multicolumn{4}{|c|}{ Вік, місяць } \\
\hline & & & 4 & 5 & 6 & 7 \\
\hline \multirow{4}{*}{$\begin{array}{c}\text { I } \\
\text { контрол. }\end{array}$} & Жива маса, кг & 27,8 & $42,2 \pm 0,328$ & $62,1 \pm 0,406$ & $84,1 \pm 0,530$ & $107 \pm 0,520$ \\
\hline & Абсолютний приріст, кг & - & $14,4 \pm 530$ & $19,9 \pm 0,650$ & $22 \pm 0,300$ & $22,9 \pm 0,191$ \\
\hline & Відносний приріст , \% & & 51,7 & 47,1 & 35,4 & 27,2 \\
\hline & Середньо добовий, г & - & $480,0 \pm 12,7$ & $663,0 \pm 20,2$ & $733,0 \pm 10,5$ & $763,0 \pm 6,30$ \\
\hline \multirow{5}{*}{$\begin{array}{c}\text { II } \\
\text { дослідна }\end{array}$} & Жива маса, кг & 28,1 & $42,6 \pm 0,254^{*}$ & $62,8 \pm 0,302^{*}$ & $85,4 \pm 0,410$ & $109,2 \pm 0,460 *$ \\
\hline & Абсолютний приріст, кг & - & $14,5 \pm 0,520^{*}$ & $20,2 \pm 0,600^{*}$ & $22,6 \pm 0,360$ & $23,8 \pm 0,560^{*}$ \\
\hline & Відносний приріст, \% & & 51,6 & 47,4 & 35,9 & 27,8 \\
\hline & Середньо добовий, г & - & $483,0 \pm 14,5^{*}$ & $673,0 \pm 12,5^{*}$ & $753,0 \pm 12,54$ & $793,0 \pm 18,93^{*}$ \\
\hline & \% до контрольної & - & 100,7 & 101,5 & 102,7 & 103,9 \\
\hline \multirow{5}{*}{$\begin{array}{c}\text { III } \\
\text { дослідна }\end{array}$} & Жива маса, кг & 28,0 & $42,9 \pm 0,260 *$ & $63,6 \pm 0,310^{*}$ & $86,9 \pm 0,470$ & $111,7 \pm 0,420^{*}$ \\
\hline & Абсолютний приріст, кг & - & $14,9 \pm 0,420^{*}$ & $20,7 \pm 0,390^{*}$ & $23,3 \pm 0,140$ & $24,8 \pm 0,670^{*}$ \\
\hline & Відносний приріст, \% & & 53,2 & 48,3 & 36,6 & 28,5 \\
\hline & Середньо добовий, г & - & $497,0 \pm 17,4^{*}$ & $690,0 \pm 12,6^{*}$ & $777,0 \pm 4,84$ & $827,0 \pm 22,4^{*}$ \\
\hline & \% до контрольної & - & 102,8 & 102,5 & 103,1 & 104,2 \\
\hline
\end{tabular}


Середньодобові прирости живої маси у поросят II та III дослідних груп достовірно перевищували показники контрольної групи відповідно на 2,4\% і 5,7\%.

Порівнюючи дані про живу масу та відносний приріст слід відмітити, кращі показники поросят III дослідної групи.
На початку проведення наукового-господарського досліду, ми відібрали по 3 тварини 3 кожної групи, для проведення балансових досліджень (Ovsiannikov, 1976).

На основі отриманих результатів визначали перетравність поживних речовин, що представлена у таблиці 3.

Таблиця 3

Перетравність поживних речовин у свиней, у \% $(\mathrm{M} \pm \mathrm{m}, \mathrm{n}=3)$

\begin{tabular}{|c|c|c|c|}
\hline \multirow{2}{*}{ Показник } & \multicolumn{3}{|c|}{ Групи } \\
\hline & 1 контрольна & 2 дослідна & 3 дослідна \\
\hline Суха речовина & $70,3 \pm 3,14$ & $71,1 \pm 1,87$ & $72,7 \pm 2,81$ \\
\hline Органічна речовина & $73,0 \pm 2,77$ & $73,4 \pm 1,78$ & $75,4 \pm 2,52$ \\
\hline Сирий протеїн & $67,3 \pm 3,81$ & $68,7 \pm 3,05$ & $70,2 \pm 6,61$ \\
\hline Сирий жир & $49,5 \pm 2,10$ & $62,3 \pm 4,38$ & $59,4 \pm 4,81$ \\
\hline Сира клітковина & $27,2 \pm 4,53$ & $28,5 \pm 4,11$ & $30,9 \pm 5,08$ \\
\hline БЕР & $83,8 \pm 2,53$ & $85,7 \pm 0,93$ & $85,3 \pm 0,81$ \\
\hline
\end{tabular}

Примітка: *-P >0,05

Аналіз коефіцієнтів перетравності раціонів свиней в балансовому досліді при згодовуванні їм преміксу 3 біологічно активною речовиною “Лізоцим ГЗх" і його вмісту в раціоні вказує, що коефіцієнти перетравності поживних речовин змінилися у бік збільшення.

Введення в раціони дослідних груп преміксу 3 ферментним препаратом “Лізоцим ГЗх” мало деякий вплив на тенденції перетравності і засвоєння решти поживних речовин. В третій дослідній групі спостерігається підвищення перетравності за всіма показниками поживності.

Так, перетравність сухої і органічної речовини в дослідний період зросла на 2,4\%, жиру на 9,9\% у порівнянні $з$ контролем. Але на фоні значного зростання даного показника, його характеристика в третій дослідній групі трішки втратила цю перевагу відносно другої дослідної групи за показниками сирого жиру та БEP.

У таблиці 4 наведені дані про середньодобове споживання корму молодняком свиней на відгодівлі у різні періоди дослідів.

Витрата кормів на одиницю приросту живої маси тісно пов'язана із загальною біологічною повноцінністю раціону.

Найменші витрата кормів на одиницю приросту живої маси, була встановлена в третій піддослідній групі, що склало 3,2 корм. од., і була меншим порівняно $з$ тваринами контрольної групи та другої дослідної на 3,1 і 3,4\%.

\section{Таблиця 4}

Інтенсивність споживання корму тваринами на дорощуванні, кг на 1 голову за добу

\begin{tabular}{|c|c|c|c|}
\hline \multirow{2}{*}{ Показник } & \multicolumn{3}{|c|}{ групи } \\
\hline & I контрольна & II дослідна & III дослідна \\
\hline Щоденна фактична кількість спожитого корму, кг & 2,19 & 2,17 & 2,17 \\
\hline Всього за період, корм. од. & 262,8 & 261,3 & 261,1 \\
\hline Витрати кормів на 1 кг приросту, корм. од. & 3,4 & 3,3 & 3,2 \\
\hline
\end{tabular}

На початку та в кінці основного періоду науковогосподарського досліду у піддослідних свиней брали кров для проведення морфологічних та біохімічних досліджень.

Встановлено, що показники крові піддослідних тварин протягом усього періоду відгодівлі знаходилися в межах фізіологічної норми. Кількість білка в крові свідчить, що різниця була на користь дослідної групи, де характерна більш висока інтенсивність росту, яка склала $10,9 \%$.

Зокрема, в сироватці крові свиней дослідної групи по відношенню до контрольної групи, підвищився вміст бета-глобулінів на $6,6 \%$ та гамма-глобулінів на $19,5 \%$ і склав 14,5 та 17,1 г/л. відповідно.

Кількість альфа-глобулінів на першому відборі крові, навпаки, був майже на одному рівні. Але після закінчення досліду цей показник змінився в іншу сторону, і став більшим на 11,5\%.

Таким чином, наші дослідження показують, що введення до складу раціону свиней на відгодівлі ферментного препарату “Лізоцим ГЗх” позитивно впливає на гемопоез, сприяє покращенню біохімічних показників крові.

Економічна ефективність вирощування молодняку свиней з 3 до 8 місяців, показала, що добавка преміксу 3 “Лізоцим ГЗх" в раціоні свиней впливає на формування основних витрат та отримання чистого прибутку в розрахунку на 1 голову. Економічні показники вирощування молодняку свиней на відгодівлі наведені у таблиці 5.

Найвищий ефект на ріст і розвиток тварин було отримано при добавці ферментного препарату “Лізоцим Г3х" у кількості 2 кг/т, який в травному 
тракті підвищує доступність поживних речовин комбікормів, які згодовували молодняку свиней. Як наслідок, від реалізації 1 голови I контрольної групи було отримано 2550,9 грн; II групи - 2613,6 грн, а III 2692,8 грн.
Відповідно, чистий прибуток у контрольній групі 3 розрахунку на одну голову склав: 303,7 грн; у II групі - 371,4 грн, а III - 445,6 грн.

Таблиця 5

Економічна ефективність вирощування молодняку свиней від 3 до 8 місячного віку $(\mathrm{n}=12)$

\begin{tabular}{|c|c|c|c|}
\hline \multirow{2}{*}{ Показники } & \multicolumn{3}{|c|}{ Групи } \\
\hline & I контрольна & II дослідна & III дослідна \\
\hline Кількість тварин в групі, голів & 12 & 12 & 12 \\
\hline Приріст однієї голови за період вирощування, кг & 77,3 & 79,2 & 81,6 \\
\hline Витрачено корму, корм. од. & 262,8 & 261,3 & 261,1 \\
\hline На 1 кг приросту, корм. од. & 3,4 & 3,3 & 3,2 \\
\hline Затрати кормів всього, кг & 219 & 217,75 & 217,583 \\
\hline Вартість 1 ц комбікорму, грн & 877,3 & 879,8 & 882,3 \\
\hline Загальні витрат на вирощування 1 голови, грн & 2249,6 & 2244,1 & 2248,1 \\
\hline у тому числі: корми, грн & 1921,2 & 1915,7 & 1919,7 \\
\hline - $\quad$ & 108,6 & 108,6 & 108,6 \\
\hline інші витрати, грн & 219,8 & 219,8 & 219,8 \\
\hline Виручка від реалізації продукції, грн & 2550,9 & 2613,6 & 2692,8 \\
\hline Прибуток від реалізації продукції, грн & 301,2 & 369,4 & 444,6 \\
\hline Рівень рентабельності,\% & 13,3 & 16,4 & 19,7 \\
\hline
\end{tabular}

\section{Висновки}

1. Розроблено премікс для свиней з включенням у його склад нової біологічно активної речовини класу гідролаз, що забезпечило ефективне використання поживних речовин кормів, та сприяло підвищенню їх продуктивності.

2. Жива маса і середньодобові прирости були найвищі у третій піддослідній групі, що одержувала 3 раціоном премікс, до якого вводили біологічно активну речовину у кількості 2 кг на 1 т, і достовірно перевищували показники контрольної групи на 5,7\%. Жива маса свиней за групами підвищилась: в контрольній групі з 27,8 до 107 кг; у II (дослідній) з 28,1 до 109,2; III (дослідній) з 28,0 до 111,7 кг.

3. Аналіз перетравності раціонів свиней в балансовому досліді показав зростання засвоюваності поживних речовин. Так, в III дослідній групі перетравність сухої і органічної речовини в дослідний період зросла на $2,4 \%$, сирого протеїну - на 2,9, жиру - на 9,9\%, сирої клітковини - на 3,7\%, і БЕР - на 1,5\% у відношенні до контролю.

4. Аналіз показників крові свиней показав, що у тварин 33 піддослідної групи в кінці дослідного періоду кількість білка становила $(71,0 \pm 1,22$ г/л), що перевищило показники тварин контрольної групи на 10,9\%. Кальцій-фосфорне співвідношення в крові 7-місячних тварин залишалось у межах фізіологічної норми.

5. Згодовування нового преміксу з біологічно активною речовиною класу гідролаз у годівлі свиней з 3 до 8 місячного віку впливає на формування основних витрат та отримання чистого прибутку в розрахунку на 1 голову. Від реалізації продукції однієї голови 3 першої групи отримали 1870,5 грн, II - 1934,3 грн, III - 1989,4 грн. Рівень рентабельності виробництва свинини становив: у I (контрольній) - 13,5; II - 16,5\%; III $-19,8 \%$.

\section{References}

Anisova, N.I., Nekrasov, R.V., et al. (2014). Fermentnyye preparaty $\mathrm{i}$ ih vliyaniye na perevarimost' pitatel'nyh veshchestv. VNII zhivoynovodstva Rossel'hozakademii OOO PO "Sibbirfarm", 114-118 (in Russian).

Boyarintsev, L., Zlobina, M., Kalinogorskaya, O., et al. (2007). Opyt primeneniya biologicheski aktivnyh preparatov v svinovodstve. Svinovodstvo, 5, 9-11 (in Russian).

Cherniy, N.V., Matsenko, E.V., Shchepetilnikov, Yu.A., Maslak, Yu.V., Machula, O.S., Furda, I.V., Voronyak, V.V., \& Gutyj, B.V. (2018). Influence of the supplement "Press-Acid" on proteinmineral metabolism and resistance of piglets. Scientific Messenger of Lviv National University of Veterinary Medicine and Biotechnologies, 20(83), 320-324. doi: 10.15421/nvlvet8364

Hachkova, V.V. (2010). Rozvytok tvarynnytstva v Ukrayini cherez pryzmu zbalansovanogo vykorystannya rynku zerna. Naukovyi visnyk NTLU Ukrayiny, 20(8), 137-143 (in Ukrainian).

Karuns'kyi, O.Y. (2004). Naukove obgruntuvannia godivli svyney. Odesa (in Ukrainian).

Kozakova, N.V. (2008). Ispol'zovaniye mineral'novitaminnogo premiksa pri vyrashchivanii molodniaka sviney. Nauchnoe izdaniye. Kormleniye sel's'kohoziaystvennyh zhivitnyh I kormoproizvodstvo: ezhemesiachnyi nauchnoprakticheskiy zhurnal, 4, 35-38 (in Russian).

Maslak, O. (2015). Rozvytok vitchyznyanogo rynku svynyny. Agrobiznes s'ogodni, 11, 306 (in Ukrainian).

Ovsiannikov, A.I. (1976). Osnovy opytnogo dela v zhivotnovodstve. M.; Kolos (in Russian).

Ibatulin, I.I., Chygryn, A.I., Otchenashko, V.V., et al. (2013). Praktykum iz godivli sil's'kogospodars'kyh tvaryn. Zhytomyr: Polissia (in Ukrainian). 